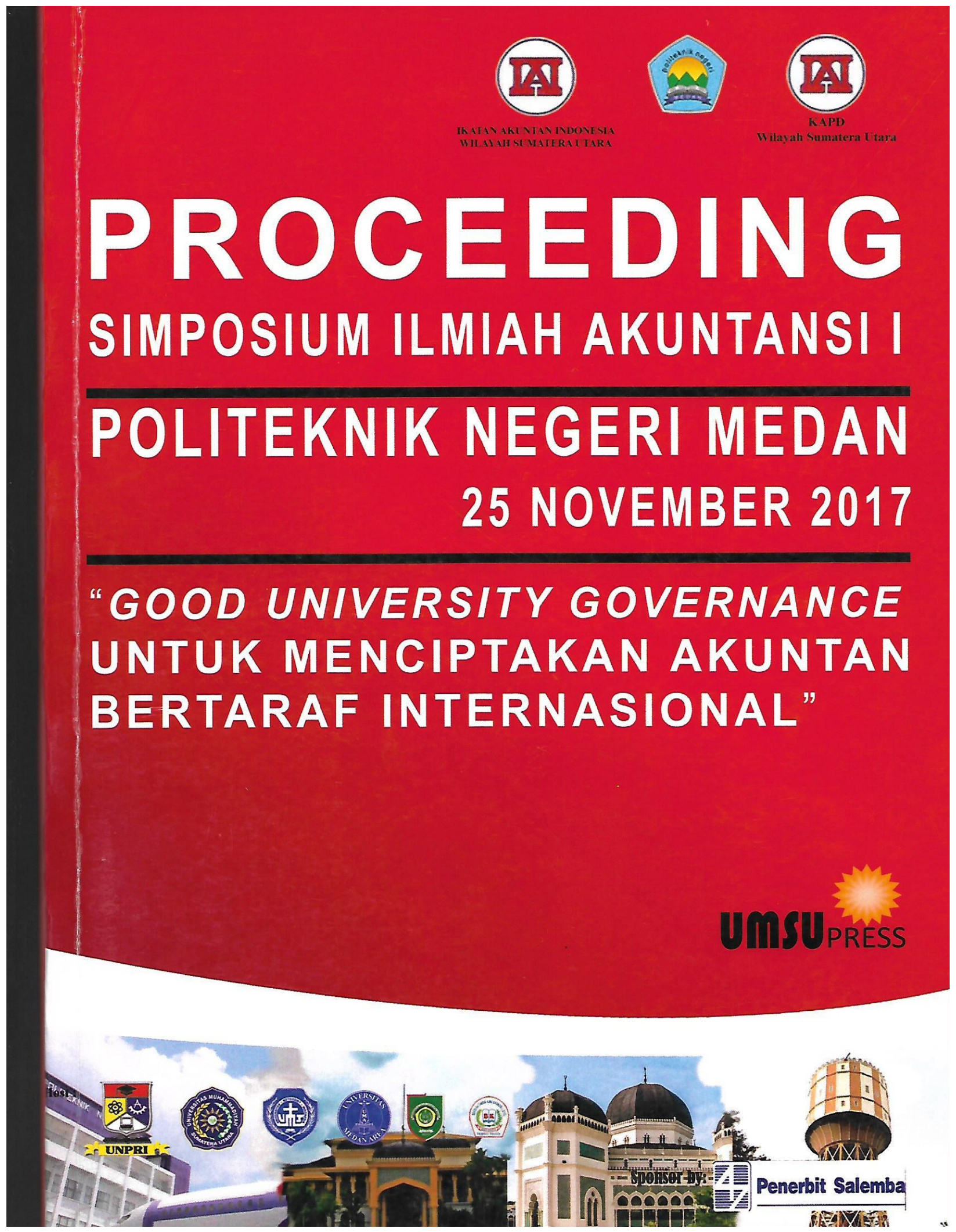




\section{NILAI WAJAR SATWA}

\author{
Muhammad Fahmi \\ Dosen STIE IBBI \\ aqilmumtazkaffi01@gmail.com
}

Minda Muliana BR Sebayang

Dosen STIE IBBI

minda_sebayang@yahoo.co.id

\author{
Riva Ubar Harahap \\ Dosen UMSU Fak. Ekonomi dan Bisnis \\ riva.ubar@yahoo.com
}

\author{
Surya Sanjaya \\ Dosen UMSU Fak. Ekonomi dan Bisnis \\ jaya_leo07@yahoo.com
}




\section{RINGKASAN}

Perusahaan Daerah (PD) Pembangunan Kota Medan Sub Unit Kebun Binatang adalah sebuah perusahaan jasa yang dikelola oleh Pemerintah Daerah Kota Medan, sama hal dengan perusahaan jasa lainnya, Perusahaan Daerah (PD) Pembangunan Kota Medan Sub Unit Kebun Binatang harus menyajikan laporan keuangan tahunan yang menyangkut posisi keuangan, kinerja, serta perubahan posisi keuangan sesuai dengan Standar Akuntansi Keuangan (SAK) yang berlaku di Indonesia.

Akan tetapi laporan keuangan yang diterbitkan Perusahaan Daerah (PD) Pembangunan Kota Medan Sub Unit Kebun Binatang tahun 2015 dan 2016 belum mencerminkan karakteristik kualitatif laporan keuangan sesuai dengan SAK, Hewan di dalam kebun binatang dapat diidentifikasi sebagai aset perusahaan, tetapi belum dapat dikelompokkan sebagai suatu aset, apakah aset lancar, aset tetap atau aset tidak tetap. Fenomena berikutnya adalah beberapa hewan belum dapat diketahui nilai wajar (fair value)nya, sebab hewan tersebut tidak diperdagangkan dan tidak memiliki nilai pasar. Hewan memiliki kesamaan karakteristik dengan aset tetap, akan tetapi penilaian estimasi persentase penyusutan dan amortisasi, masa manfaat dan nilai residu belum dapat diukur secara handal. Dari fenomena diatas terjadi permasalahan yaitu meliputi pengukuran (identifikasi, pengelompokkan dan penilaian transaksi ekonomi) sehingga memungkinkan hewan tidak dapat disajikan didalam laporan keuangan.

Penelitian ini mengedepankan paradigma kualitatif induktif, sehingga metode penyelesaian penelitian dibagi menjadi tiga bahagian yaitu pertama analisis lapangan yang hasil akhirnya berupa informasi berupa data base mengenai hewan, kedua yaitu analisis teori, dengan pendekatan pustaka melalui buku, jurnal dan SAK, IFRS, IAS yang hasil berupa model pegnidentifikasian, pengelompokan dan penilaian binatang dan ketiga analisis rancangan yang hasil akhirnya adalah model laporan keuangan sesuai dengan SAK di Indonesia.

Diharapkan penerapan metode tersebut dapat menyelesaikan permasalahan penelitian ini, sehingga tujuan jangka panjang pada penelitian ini yaitu memberikan rekomendasi kebijakan dalam tiga hal, pertama yaitu penerapan PSAK 69 adaptasi dari IFRS 41 tentang aset biologis. Kedua, penerapan PMK No.247/PMK.06/2014 tentang aset tetap dan ketiga yaitu penerapan UU No. 36 Tahun 2008 Tentang Pajak Penghasilan,

Dari hasil pengamatan diperoleh koleksi satwa sebanyak 38 satwa, yang masing masing terdiri dari kelas aves sebanyak 20 jenis satwa, mamalia sebanyak 11 jenis satwa dan reptile sebanyak 7 jenis satwa, menurut UU No. 5 Tahun 1990 , PP No. 07 Tahun 1999 dan PP No 08 tahun 1999 sebanyak 21 satwa dilindungi sehingga nilai wajar satwa tidak dapat ditentukan, akan tetapi, satwa yang tidak dilindungi dan kategori cites appendix II sebanyak 10 satwa dapat ditentukan nilai wajar dapat ditentukan karena dapat diperdagangkan.

\section{Kata Kunci : Nilai Wajar}




\section{SUMMARY}

The Development District Company of Medan Sub Unit Zoo is a service company which is managed by the Government of Medan, it is equal to another service company, The Development District Company of Medan Sub Unit Zoo must present annual financial statement dealing to financial position, performance, and the change of financial position in according to the valid Standart Akuntansi Keuangan (SAK)-(Financial Accountancy Standard) in Indonesia

However the published financial statement of Perusahaan Daerah (PD) Pembangunan Kota Medan Sub Unit Kebun Binatang (The Development District Company of Medan Sub Unit Zoo) year 2015 and 2016 does not reflect the characteristic of appropriate qualitative financial statement yet with SAK. The animal in the zoo can be identified as company asset, but cannot be categorized yet as an asset, whether current asset, fixed asset or non fixed asset. Another phenomenon is some animals cannot be detected their own fair value, because those animals are not for trade and have no market price. The animal has similar characteristic with asset tetap (fixed asset), but the estimation assessment of depreciation percentage and amortization, useful life and residue value cannot be measured yet trustfully. By the phenomenon, the problem comes up that is measurement (identification, categorization, and the assessment of economy transaction) so that it is enable for animal cannot be presented in the financial statement.

This research prioritize the paradigm of Inductive qualitative, so that the method in resolving the research divided into three part namely; first, field analysis which its final result is the information in the form of database concerning the animals; second, theoretical analysis, the reference approach via books, journals and SAK, IFRS, IAS the result is identification modl, categorization and animal assessment; and third design analysis - the final result is financial statement in accordance with SAK in Indonesia.

Hopefully the applied method can help in resolving the problem of this research, so the long-term goal of this research can give the policy recommendation in three subject matters; first the implementation of PSAK 69 adopted from IFRS 41 concerning biological asset; second, the implementation of PMK No. 247/PMK.06/2014 concerning the fixed asset ; and third the implementation of UU (regulation) No.36 year 2008 concerning Income tax.

Based on the observation result, it is acquired that animal collections as many as 38 animals, each consists of 20 species for aves class, 11 species for mammals and 7 species for reptile. According to UU No. 5 year 1990 , PP No. 07 year 1999 and PP No 08 year 1999 there are 21 protected animals, so that the fair value cannot be determined, but the unprotected animals and the category of cite appendix II as many as 10 animals can be determined due to enable to be traded.

Keyword : Fair value 


\section{Pendahuluan.}

\subsection{Latar Belakang.}

Kebun Binatang adalah entitas perusahaan jasa yang keseluruhan pendapatannya diperoleh dari penjualan tiket, dari pembelian tiket tersebut masyarakat dapat melihat dan memanfaatkan keanekaragaman flora (tanaman) dan fauna (hewan) dan tempat taman - taman rekreasi yang terdapat di dalam kebun binatang tersebut. Perusahaan Daerah (PD) Pembangunan Kota Medan Sub Unit Kebun Binatang adalah perusahaan kebun binatang dikelola oleh Pemerintah Daerah (Pemda) Kota Medan. Peraturan Pemerintah (PP) No. 08 Tahun 2006 mewajibkan setiap perusahaan daerah menyusun laporan keuangan tahunan dengan menerapkan Standar Akuntansi Pemerintahan (SAP) dan PSAK 45 wajib dilaksanakan jika perusahaan tersebut berbentuk Badan Layanan Umum (BLU) atau Taman Margasatwa atau disebut non - profit oriented. Dan Undang - Undang No 17 Tahun 2003 menekankan bahwa tanggung jawab pemerintah daerah adalah menyusun laporan keuangan pemerintah daerah yang dilampiri laporan keuangan perusahaan daerah, dan ditetapkan juga bahwa laporan keuangan pemerintah harus diaudit oleh Badan Pemeriksa Keuangan Republik Indonesia (BPK - RI).

Menurut laporan keuangan yang diterbitkan Perusahaan Daerah (PD) Pembangunan Kota Medan Sub Unit Kebun Binatang tahun 2015 dan 2016, seluruh hewan yang dimiliki (dikuasai) oleh perusahaan tidak dicatat dan diakui pada laporan keuangan perusahaan tersebut, keberadaan hewan di perusahaan hanya dicatat sebagai beban pada laporan aktivitas dan perubahan aset bersih, misalnya beban konservasi, beban pemeliharaan, beban penelitian dan pengembangan dan beban lain sebagainya.

Karakteristik hewan memiliki kesamaan atas aset, jika perusahaan memperoleh suatu hewan untuk dimiliki dan dikuasi untuk tujuan mengharapkan manfaat ekonomis dimasa akan datang, maka hewan dapat diklasifikasikan sebagai aset, akan tetapi penjelasan dalam Internastional Accounting Standard (IAS) 41 tentang Agriculture yang diadopsi oleh Pedoman Standar Akuntansi Keuangan di Indonesia (PSAK) 69 tentang Aset Biologis hanya berlaku pada perusahaan perkebunan dan peternakan, akan tetapi tidak dapat diterapkan pada perusahaan kebun binatang, hal ini disebabkan sulitnya menentukan nilai 
wajar (fair vaule) setiap jenis hewan yang dimiliki oleh perusahaan, akibat keterjadian peristiwa ini akan dapat menyebabkan distorsi akuntansi karena suatu standar gagal menangkap realita ekonomi (Wild, Subramanyam and Halsey.2008;15).

Mengenai interprestasi PSAK No.16 tentang aset tetap dan aset lain - lain, menjelaskan bahwa suatu hewan yang dimiliki oleh kebun binatang tidak dapat diklasifikasikan sebagai aset tetap dan aset lain - lain, dikarenakan tidak adanya nilai yang pasti mengenai umur manfaat, persentase beban amortisasi dan nilai residu untuk setiap jenis hewan. Jika suatu hewan diperoleh dengan cara hibah, maka dicatat sesuai nilai wajarnya, akan tetapi sulit untuk menentukan nilai wajar dengan harga pasar apabila suatu jenis hewan diklasifikasikan sebagai hewan yang dilindungi dan tidak untuk diperdagangkan.

Khususnya di Negara Indonesia, akuntansi keuangan dan pajak berbeda, laba kena pajak pada dasarnya adalah laba akuntansi keuangan yang disesuaikan terhadap perbedaan dengan hukum pajak, maka dengan demikian akuntansi keuangan dan pajak terpisah (Choi and Meek.2006;67). Direktorat Jendral Pajak (DJP) Republik Indonesia mengeluarkan Peraturan UU No. 36 Tahun 2008 tentang Pajak Penghasilan yang menjelaskan bahwa laba kena pajak diperoleh dari penyesuaian menurut peraturan perundang - udangan perpajakan yang berlaku. Dengan demikian, apabila dari seluruh hewan yang dimiliki oleh perusahaan tidak dicatat dan diakui pada laporan keuangan, maka dapat menghilangkan potensi pajak.

\subsection{Permasalahan Penelitian.}

Di beberapa kebun binatang, kepemilikan atas koleksi hewan belum dicatat dan disajikan pada laporan keuangan akhir tahun, berikut ini menyajikan penjelasan dari laporan auditor independen atas pemeriksanaan beberapa perusahaan kebun binatang dibeberapa negara.

- Berdasarkan laporan auditor independen Chon Reznick atas pemeriksaan laporan keuangan konsolidasi Zoological Society of San Diego dba San Diego Zoo Global pada periode 7 Desember 2015 dan 1 Januari 2017, menjelaskan bahwa : 
Animal and holticultural Collections

In accordance with customary practice among Zoological organizations, animal and horticultural collections are recorded at the nominal amount of one dollar, as there is no objective basis for establishing value. Additionally, animal and horticultural collections have numerous attributes, including species, age, sex, relationship and value to other animals, endangered status, and breeding potential, whereby it impracticable to assign value. Expenditures related to animal and horticultural acquisitions are expensed in the period of acquisition.

- Atas laporan auditor independen Hendry and Horne, LLP atas pemeriksaan laporan keuangan konsolidasi Arizona Center for Nature Conservation and Affiliate, pada tahun berakhir 30 Juni 2014 dan 2015 menjelaskan bahwa :

$\underline{\text { Animals }}$

In Accordance with industry practice, the animal collection is not rccorded, as there is no objective basis for establishing value. Additionally, the animal collection has numerous attributes, including species, age, sex, relationship and value to other animals, endangered status, and breeding potential, whereby it impracticable to assign value. Acquisitions and Sales of animal are recorded as operating expense or revenue in the year of purchase or sale.

- Berdasarkan laporan auditor independen Verdeja, De Armas, Trujillo atas pemeriksaan laporan keuangan Zoo Miami Foundation, Inc untuk tahun berakhir 30 September 2014 dan 2015 pada catatat atas laporan keuangan perusahaan tidak mengungkapkan informasi mengenai hewan.

- laporan auditor independen Mazars LLP atas pemeriksaan laporan keuangan Marwell Wildlife untuk tahun berakhir 31 Desember 2015, menjelaskan bahwa :

$\underline{\text { Animals }}$

Marwell wildlife participates in global cooperative efforts to maintain sustainable populatios of animals which reliant on the sharing of individuals between zoological organizations. Veterinary screening, transport and other cost of receiving animals are expensed during the period of acquisition. However, with no objective or practical basis for esthablishing value, animal transactions are made without monetary consideration. Hence, as is customary among zoological organisations, the animal collection is recorded at a nominal value

- Berdasarkan laporan auditor independen Will Baker dari KPMG LLP atas pemeriksaan laporan keuangan The North of England Zoological Society, tahun berakhir 31Desember 2015, tidak mengungkapkan informasi tentang hewan pada catatan atas laporan keuangan tersebut. 
- Berdasarkan laporan auditor independen Scott dan Company atas pemeriksaan laporan keuangan Richland-lexington Riverbanks Park District, untuk tahun fiscal yang berakhir 30 Juni 2014, tidak mengungkapkan informasi tentang hewan pada catatan atas laporan keuangan tersebut.

- Laporan auditor independen Clifton Larson Allen LLP atas pemeriksaan laporan keuangan Saint Louis Zoo tahun berakhir 31 Desember 2016, menjelaskan bahwa :

Animals Transactions

Animal transactions that do not involve either the receiving or disbursing of cash are not recorded in the Zoo's financial statement, Those transactions that involve cash are recorded on the accrual basis of accounting in the period the animal was shipped or received.

- Laporan auditor independen Mari-Anne Williamson atas pemeriksaan laporan keuangan Wellington Zoo untuk tahun berakhir 30 Juni 2016, menjelaskan bahwa :

Animals Collections

In accordance with customary practice among Zoological organizations, animal are not recorded as there is no objective basis for establishing value. Additionally, animal have numerous attributes, including species, age, sex, relationship and value to other animals, endangered status, and breeding potential, whereby it is impracticable to assign value. Expenditures related to animal acquisitions is expensed in the period of acquisition

\subsection{Rumusan Penelitian.}

Dari permasalahan penelitian diatas, Adapun rumusan masalah pada penelitian ini yaitu , Perusahaan Daerah (PD) Pembangunan Kota Medan Sub Unit Kebun Binatang, tidak menyajikan dan mengungkap koleksi satwa pada laporan keuangan pada tahun 2015 dan 2016, disebabkan sulitnya menentukan nilai wajar. (fair value)

\subsection{Tujuan Penelitian.}

Adapun tujuan penelitian ini, melakukan kajian mengenai penetapan nilai wajar dengan pendekan PSAK 69 dan IFRS 41 pada setiap koleksi satwa pada Perusahaan Daerah (PD) Pembangunan Kota Medan Sub Unit Kebun Binatang, sehingga dapat disajikan pada laporan keuangan dimasa akan datang. 


\section{Kerangka Koseptual dan Pengembangan Hipotesis.}

Laporan keuangan adalah hasil dari proses akuntansi, akuntansi mencakup proses pengukuran, pengungkapan dan auditing (Choi and Meek 2006). Dimana pengukuran meliputi serangkaian pengidentifikasian, pengelompokkan dan menghitung entitas ekonomi. Perhitungan nilai ekonomi harus memenuhi nilai wajar (fair value). menurut Pedoman Standar Akuntansi Keuangan (PSAK) 16 (IAI.16.2) nilai wajar adalah suatu jumlah, untuk itu suatu aset mungkin ditukar atau suatu kewajiban diselesaikan antara pihak yang memahami dan berkeinginan untuk melakukan transaksi wajar (arm's lenght transaction). Kemudian International Financial Reporting Standards (IFRS) No.13 (2012.9) fair value as the price that would be received to sell an asset or paid to transfer a laibility in an orderly transaction between market participants at the measurement date, IFRS 13 menjelaskan bahwa harga yang digunakan di pasar (market based measurement) sebagai dasar pengukuran nilai wajar, bukan berdasarkan harga yang tergantung pada faktor internal perusahaan (entity specific measument), kata "orderly transaction" adalah transaksi dalam keadaan wajar teratur, yaitu harga dari faktor internal dapat dipakai apabila harga yang digunakan dipasar tidak ada.

International Accounting Standard (IAS) 41 explained that a biological asset is a living animal or plant. Hewan dan tumbuhan disebut sebagai aset biologis karena memiliki proses tumbuh, degenerasi, produksi dan prokreasi yang mengakibatkan perubahan kuantitas dan kualitas pada aset biologis itu sendiri. Adapun pengukuran nilai wajar pada IAS 41 berdasarkan IFRS 13 yaitu harga yang digunakan di pasar. Berdasarkan PSAK 68 (IAI. 2013 27.34) teknik penilaian dari nilai wajar terdiri tiga pendekatan, Pendekatan pasar (market approach) dimana menggunakan harga dan informasi relevan lain yang dihasilkan oleh transaksi pasar yang melibatkan aset, liabilitas yang identik yang serupa. Pendekatan biaya (cost approach) mencerminkan jumlah yang dibutuhkan saat ini untuk menggantikan kapasitas manfaat (servive capacity) aset, Pendekatan penghasilan (income approach) mengkonversi jumlah masa depan ke suatu jumlah tunggal saat ini. 
IAS 20 diadopsi secara penuh oleh PSAK 61 (IAI. 2010) defenisi hibah pemerintah adalah bantuan pemerintah yang memenuhi syarat entitas harus melalukan pembelian, membangun atau membeli aset jangka panjang, ruang lingkup IAS 20 tidak termasuk IAS 41 yang diadopsi oleh PSAK 69, penilaian nilai wajar IAS 20 merujuk IFRS 13 yaitu harga yang digunakan di pasar dan transaksi dalam keadaan wajar teratur. Dan PSAK 16 menjelaskan aktiva donasi adalah aktiva yang diperoleh dari sumbangan di catat sebesar harga taksiran atau harga pasar dengan mengkreditkan Modal Donasi,

Dari fakta pengugkapan atas laporan keuangan kebun binatang atas ketidakmampuan untuk mengukur nilai wajar dari semua yang material atas hewan akan menurunkan nilai kualitas kualitatif laporan keuangan, menurut SAK (IAI 2004,08) materialitas adalah jika kelalaian untuk mencantumkan atau kesalahan dalam mencatat informasi yang dapat mempengaruhi keputusan ekonomi pemakai yang diambil atas dalam laporan keuangan.

Penner and Saini (2015) mengungkap fakta bahwa Zoo World membeli lima jantan dan betina jerapah dengan masing - masing harga $\$ 25.000$, biaya tambahan dokter hewan sebesar $\$ 10.000$ dan biaya jaminan dan transportasi sebesar $\$ 20.000$, biaya makan sebesar $\$ 3.000$ per tahun, dan biaya pengembangbiakan sebesar $\$ 10.000$ per tahun, Zoo World menukar jerapah dengan keledai mesir dari kebun binatang lain dengan nilai wajar sebesar \$15.000 dan \$20.000 secara tunai. Sejalan dengan PSAK (IAI.2004.20) dalam pengakuan (recognition) pos memiliki unsur yaitu ada manfaat ekonomi yang berkaitan dengan pos akan mengalir kedalam perusahaan dan pos mempunyai nilai dan biaya dapat diukur secara handal, dan PSAK (IAI.2004.21) biaya dan nilai harus diestimasi. Menurut Kaur (2013) hewan dan tumbuhan dapat diukur nilai wajarnya apabila memiliki nilai pasar dan biaya pada saat penilaiannya dan hewan dicatat sebagai aset tetap dan diamortisasi (Reeve.2009).

Pengungkapan fakta diatas sesuai IFRS 13 bahwa aset hewan memungkinkan dapat ditentukan nilai wajarnya, dan apabila transaksi dalam keadaan wajar teratur maka estimasi bisa menggunakan jasa penilai publik sesuai PMK No. 101/PMK.01/2014 pada Pasal 05 Point (3) huruf e yaitu bidang jasa penilaian 
properti meliputi pertanian, perkebunan, peternakan, perikanan dan kehutanan. Pengungkapan fakta tersebut bisa tidak dapat terjadi sebab manfaat lebih kecil dari biaya (Stice, Stice and Skousen 2009).

\subsection{Kerangka Konseptual.}

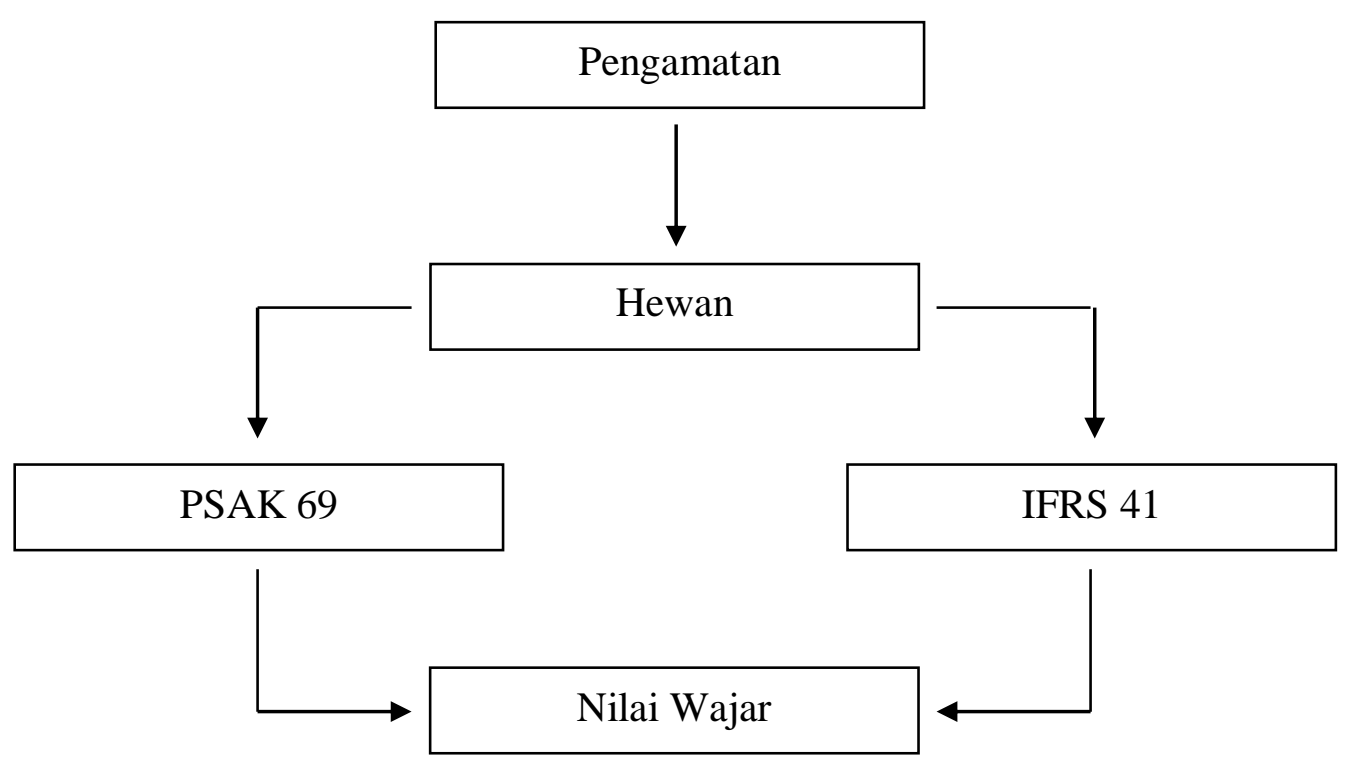

\section{Gambar 1 \\ Kerangka Konseptual \\ Nilai Wajar Satwa Dengan Pendekatan IFRS 41 dan PSAK 69}

\section{Metode Penelitian.}

\subsection{Pendekatan Penelitian}

Paradigma penelitian ini adalah adalah penelitian kualitatif induktif yaitu merupakan penelitian yang menekankan pada pemahaman mengenai masalah - masalah dalam kehidupan sosial berdasarkan kondisi realitas dan natural setting yang holistis, kompleks dan rinci dengan cara menyusun konstruksi teori atau hipotesis melalui pengungkapan fakta. (Erlina dan Mulyani 2007). Cara pendang penelitian induktif mengutamakan eksplorasi data terlebih dahulu sebagai pijakan awal, artinya teorisasi bukan hal 
penting untuk dilakukan untuk melakukan awal penelitian. Pengumpulan data pada penelitian pendekatan kualitatif ini yaitu melalui, wawancara dan pengamatan pada subjek dan objek penelitian (Bungin, 2008).

\subsection{Lokasi Penelitian.}

Lokasi Penelitian terdiri dari dua yaitu pada Perusahaan Daerah (PD) Pembagunan Kota Medan di Jalan Sutomo Ujung No. 04 Kode Pos 20235, Kecamatan Medan Timur, Kotamadya Medan. Provinsi Sumatera Utara. Dan Kebun Binatang Medan Jalan. Bunga Rampai IV No. 100 Kode Pos 20135. Kelurahan Simalingkar, Kecamatan Medan Tuntungan, Provinsi Sumatera Utara

\subsection{Subjek Penelitian.}

Adapun subyek penelitian ini sebagai sumber data penelitian kualitatif adalah seluruh hewan yang berada di Perusahaan Daerah (PD) Pembangunan Kota Medan Sub Unit Kebun Binatang.

\section{Hasil Penelitian.}

Dari hasil pengamatan pada subjek penelitian di Perusahaan Daerah (PD) Pembangunan Kota Medan Sub Unit Kebun Binatang, pada (appendix 1) menjelaskan koleksi berjumlah 38 jenis satwa, yang masing - masing terdiri dari kelas aves sebanyak 20 jenis satwa, mamalia sebanyak 11 jenis satwa dan reptile sebanyak 7 jenis satwa.

Adapun jenis satwa yang dilindungi dan tidak dapat untuk diperdagangakan menurut UU No. 5 Tahun 1990 , PP No. 07 Tahun 1999 dan PP No 08 tahun 1999 adalah sebagai berikut :

\section{Tabel 1}

Satwa yang Dilindungi UU No. 5 Tahun 1990 , PP No. 07 Tahun 1999 dan PP No 08 tahun 1999

\begin{tabular}{clllll}
\hline No & \multicolumn{1}{c}{ Nama } & \multicolumn{1}{c}{ Nama Latin } & \multicolumn{1}{c}{ Kelas } & \multicolumn{1}{c}{ Ordo } & \multicolumn{1}{c}{ Familia } \\
\hline 1 & Bayan (Burung) & - & Aves & Psittaciformes & Cacatuidae \\
2 & Kakatua Raja & Probasciger Aterrimus & Aves & Psittaciformes & Cacatuidae \\
3 & Kakatua Jambul Kuning & Loptura Nycthemera & Aves & Psittaciformes & Cacatuidae \\
4 & Merak Hijau & Pavo Muticus & Aves & Galliformes & Phasianidae \\
5 & Bangau Tong Tong & Leptoptilos Javanicus & Aves & Ciconiiformes & Ciconiidae \\
6 & Burung Kuntul & Ergretta Gazetta & Aves & Ciconiformes & Ardeidea \\
7 & Elang Ular & Cacatuica & Aves & Accipitriformes & Accipitridae \\
8 & Elang Bondol & Haliastur Indus & Aves & Falconiformes & Accipitridae \\
9 & Kura - Kura Brazil & Trachemys Scripta Elegans & Reptile & Psittaciformes & Cacatuidae \\
10 & Penyu Sisik & Eretmochelys Imbricata & Reptile & Testudinata & Cheloniidae \\
\multicolumn{4}{c}{ Simposium Ilmiah Akuntansi I, IAI - KAPD Sumatera Utara, 2017 12 }
\end{tabular}




\begin{tabular}{llllll}
11 & Dara Mahkota & Goura Victoria & Aves & Columbiformes & Columbidae \\
12 & Landak & Hystrix Brachyura & Mamalia & Rodenti & Hystricideage \\
13 & Elang Laut Perut Putih & Haliaeetus Leucogaster & Aves & Falconiformes & Accipitridae \\
14 & Harimau Sumatera & Panthera Tigris Sumatra & Mamalia & Carnivora & Felidae \\
15 & Beruang Madu & Helarctos Malaynus & Mamalia & Carnivora & Ursidae \\
16 & Rusa Timor & Cervus Timorensis & Mamalia & Artiodactyla & Cervidae \\
17 & Kucing Emas & Felis Temmincki & Mamalia & Carnivora & Felidae \\
18 & Rusa Sambar & Cervus Unicolor & Mamalia & Artiodactyla & Cervidae \\
29 & Buaya Muara & Crocodylus Porosus & Reptile & Crocodilia & Crocodylidae \\
20 & Buaya Senyulong & Tomistoma Schlegelii & Reptile & Crocodilia & Crocodylidae \\
21 & Kasuari & Casuarius Casuarius & Aves & Casuariformes & Casuariidae \\
\hline
\end{tabular}

Sumber : Appendix 1

Pada tabel 1 diatas untuk keseluruhan satwa, sesuai UU No 5 tahun 1990, PP No. 07 tahun 1999 dan PP No 08 tahun 1999 adalah satwa yang dilindungi atau tidak dapat diperdagangkan (diperniagakan). jika satwa tersebut dilindungi dan tidak dapat diperdagankan maka sulit menentukan nilai wajarnya.

Tabel 2

\section{Satwa yang tidak dilindungi dan Cites Appendix II}

\begin{tabular}{|c|c|c|c|c|c|}
\hline No & Nama & Kelas & Ordo & Familia & Status \\
\hline 1 & Nuri Kepala Hitam & Aves & Psittaciformes & Psittaculidae & Cites Appendix II \\
\hline 2 & Kakatua Maluku & Aves & Psittaciformes & Cacatuidae & Cites Appendix II \\
\hline 3 & Burung Hantu & Aves & Stringiformes & Strigdae Nocturnal & Cites Appendix II \\
\hline 4 & Kowak Malam Abu Abu & Aves & Ciconiformes & Ardeidea & Tidak Dilindungi \\
\hline 5 & Elang Ular Bido & Aves & Accipitriformes & Accipitridae & Cites Appendix II \\
\hline 6 & Biawak & Reptile & Squamata & Varanidae & Cites Appendix II \\
\hline 7 & Ular Sanca Jarring & Reptile & Squamata & Phiyhonidae & Cites Appendix II \\
\hline 8 & Kuda & Mamalia & Parissodactyla & Equidae & Tidak dilindungi \\
\hline 9 & Kelinci & Mamalia & Lagormorpha & Leporidedae & Tidak Dilindungi \\
\hline 10 & Merpati & Aves & Columbiformes & Columbidae & Tidak Dilindungi \\
\hline
\end{tabular}

Sumber : Appendix 1

Tabel 2 menjelaskan bahwa terdapat 10 jenis satwa termasuk pada status tidak dilindungi dan Cites Appendix II, status tidak dilindungi memungkinkan dapat menentukan nilai wajar suatu satwa, sebab satwa tersebut diperdagangakan, begitu juga status Cites Appendix II, termasuk pada lampiran daftar satwa dari spesies yang tidak terancam kepunahan, akan tetapi adanya suatu pengaturan pemerintah tentang perdagangannya. Dengan demikian satwa pada status tidak dilindungi dan Cities Appendix II memungkinkan dapat ditentukan nilai wajarnya. 


\section{Kesimpulan, Implikasi dan Keterbatasan.}

\subsection{Kesimpulan.}

Dari hasil penelitian sebelumnya, maka kesimpulan penelitian ini adalah sebagai berikut :

1. Dari hasil pengamatan, apabila satwa pada status dilindungi maka tidak dapat ditentukan nilai wajarnya.

2. Dari hasil pengamatan, apabila satwa pada status tidak dilindungi dan Appendix Cites II, memungkinkan dapat ditentukan nilai wajarnya. Sebab satwa tersebut diperdagangkan.

\subsection{Implikasi.}

Pada saat ini laporan keuangan yang diterbitkan Perusahaan Daerah (PD) Pembangunan Kota Medan Sub Unit Kebun Binatang tahun 2015 dan 2016, tidak mencatumkan seluruh koleksi satwa disebabkan tidak memiliki nilai wajar. Hasil penelitian ini membuktikan sebanyak 10 jenis satwa dari keseluruhan sebanyak 38 jenis satwa, memungkinkan dapat ditentukan nilai wajarnya, dengan demikian, jika satwa tersebut dapat ditentukan nilai wajarnya maka dapat disajikan pada laporan keuangan periode dimasa akan datang.

\subsection{Keterbatasan.}

Adapun keterbatasan penelitian ini adalah sebagai berikut :

1. Pengamatan subjek penelitian dalam menetapkan nilai wajar, dilakukan pada pengamatan tingkat awal, pengamatan dilakukan dengan dokumentasi foto pada setiap satwa dan menbandingkannya dengan realita yang ada berdasarkan pengalaman penelitian.

2. Peneliti belum melakukan wawancara kepada pihak manajemen dan pengujian data pada setiap satwa.

3. Peneliti belum melakukan survey lanjutan, mengenai nilai pasar setiap satwa yang tidak dilindungi. 


\section{Reference.}

Annual Report Wellington Zoo, Year Ended June 30, 2016. https://wellingtonzoo.com/assets/Resources/Wellington-Zoo-Annual-Report-201516.pdf. in access on 28 Agustus 2017.

Bungin, Burhan. 2008. Metode Penelitian Kualitatif. Penerbit. Raja Grafindo Persada. Indonesia.

Choi F. D.S and Meek G. K .2006. International Accounting. Pearson Prentice Hall.

Consolidated Financial Statements and Independent Auditor's Report of Zoological Society of San Diego dba San Diego Zoo Global ended years Januari 1, 2017 and December 7, 2015.

http://zoo.sandiegozoo.org/sites/all/themes/zoostrap/downloads/financialreports/SDZG2016FinancialStatement.pdf di akses pada 27 Agustus 2017.

Consolidated Financial Statements and Independent Auditor's Report Arizona Center for Nature Conservation and Affiliate, Years Ended June 30, 2015 and 2014 http://www.phoenixzoo.org/wp-content/uploads/2016/04/Arizona-Center-for-NatureConservation-2015-Audited-Financial-Statement.pdf. di akses pada 28 Agustus 2017

Erlina dan Mulyani, S. 2007. Metodologi Penelitian Bisnis untuk Akuntansi dan Manajemen. USU Press Medan.

Financial Statements and Independent Auditor's Report Zoo Miami Foundation, Inc. Years Ended September 30, 2015 and 2014. http://www.zoomiami.org/sites/default/files/files/Audited\%20Financials\%20FY'15.pdf di akses pada 28 Agustus 2017.

Financial Statements and Supplementary Information Saint Louis Zoo, Zoological Subdistrict of the Metropolitan Zoological Park and Museum District and Saint Louis Zoo Association ST. Louis, Missouri, Year Ended December 31, 2016 https://www.stlzoo.org/download_file/view_inline/6452/152/ di akses pada 28 Agustus 2017.

International Financial Reporting Standar (IFRS) 13 Fair Value Measurement. International Accounting Standards Board (IASB)

International Accounting Standard (IAS) 41 Agriculture, International Accounting Standards Board (IASB) http://ec.europa.eu/internal_market/accounting/docs/consolidated/ias41_en.pdf di akses pada 25 Agustus 2017

Internastional Accounting Standar (IAS) 20 Accounting for Goverment Grants and Disclouser of Goverment Assistance. International Accounting Standards Board (IASB) 
Kaur. J. 2013. The Fairness of the Fair Value Concept. International Journal of Bussiness and Commerce. Vol.3.No.3. Nov 2013 [01-10] wwww.ijbnet.com

Laporan Keuangan Perusahaan Daerah (PD) Pembangunan Kota Medan Sub Unit Kebun Binatang tahun 2015 dan 2016

Stice. J. D, Stice E. K and Skousen K.F .2009 Intermediate Accounting. Edisi 16 Cengange Learning. Salemba Empat. Jakarta

Reeve, JM, Warren C.S and Duchac J.E. 2009. Priciples of Accounting Indonesia Adaption, Buku 1. Cengange Learning. Salemba Empat. Jakarta.

Report and Audit of Financial Statements of Richland-Lexington Riverbanks Park District, for the Fiscal Year Ended June 30, 2014.

https://www.riverbanks.org/about/downloads/riverbanks_zoo_commission_final_audit_2 014.pdf di akses pada 28 Agustus 2017.

Trustees' Report and Financial Statements Marwell Wildlife, For the year ended 31 December 2015.

https://www.marwell.org.uk/media/other/mw_final_signed_accounts_for_2015.pdf di akses pada 28 Agustus 2017

Trustees' Report and Financial Statements The Noth of England Zoological Society. Year Ended 31 st December 2015. http://www.chesterzoo.org/ /media/files/global/annual\%20reports/2015-

appendices/review\%20accounts\%2032pp_lo-res.pdf?la=en . di akses pada 28 Agustus 2017

Undang - undang No. 36 Tahun 2008 tentang Pajak Penghasilan dan Peraturan Pelaksanaannya, Kementerian Keuangan Direktorat Jendral Perpajakan RI.

http://jdih.esdm.go.id/peraturan/UU\%20No.\%2036\%20Thn\%202008.pdf. di akses pada 26 Agustus 2017.

Undang - undang No. 17 Tahun 2003 Tentang Keuangan Negara. http://www.bpk.go.id/assets/files/storage/2013/12/file storage 1386152419.pdf Di akses tanggal 25 Agustus 2017

Undang - undang No. 5 Tahun 1990 Tentang Konservasi Sumberdaya Alam Hayati Dan Ekosistemnya. http://indonesiabch.or.id/docs/uu5-1990.pdf di akses pada 6 Oktober 2017

Pedoman Standar Akuntansi Keuangan (PSAK) No. 14 .2004 tentang Aset Tetap, Ikatan Akuntansi Indonesia. Dewan Standar Akuntansi Keuangan Ikatan Akuntan Indonesia (DSAK-IAI). www.iaiglobal.or.id 
Pedoman Standar Akuntansi Keuangan (PSAK) No. 16. 2010. Aktiva Tetap dan Aktiva Lain lain, Dewan Standar Akuntansi Keuangan Ikatan Akuntan Indonesia (DSAK-IAI). www.iaiglobal.or.id

Pedoman Standar Akuntansi Keuangan (PSAK) No. 68. 2013 Pengukuran Nilai Wajar, Dewan Standar Akuntansi Keuangan Ikatan Akuntan Indonesia (DSAK-IAI). www.iaiglobal.or.id

Pedoman Standar Akuntansi Keuangan (PSAK) No. 61. 2010. Akuntansi Hibah Pemerintah dan Pengungkapan Bantuan, Dewan Standar Akuntansi Keuangan Ikatan Akuntan Indonesia (DSAK-IAI). www.iaiglobal.or.id

Pedoman Standar Akuntansi Keuangan (PSAK) No. 69. 2015. Aset Biologis, Dewan Standar Akuntansi Keuangan Ikatan Akuntan Indonesia (DSAK-IAI). https://staff.blog.ui.ac.id/martani/files/2016/03/ED-PSAK-69-07-Sept-20153.pdf di akses pada 26 Agustus 2017

Price W.C. 2014. Independent Auditor's Report and Financial Statements Toronto Zoo. December 27, 2014. www.pwc.com/ca

Penner, J W and Saini, J S . 2015. Accounting for Giraffes at a For - Profit Zoo - A Case Study, International Journal of Accounting and Financial Reporting, Macrothink Institute Vol. 5, No.1. ISSN 2162 - 3082.www.macrothink.org/ijafr

Peraturan Menteri Kuangan (PMK) Republik Indonesia No. 101/PMK.01/2014 Tentang Penilai Publik. No reg. 719,2014

Peraturan Menteri Kuangan Republik Indonesia No. 247/PMK.06/2014 Tentang Perubahan Kedua Atas Peraturan Menteri Keuangan No. 01/PMK.06/2013 Tentang Penyusutan Barang Milik Negara Berupa Aset Tetap Pada Entitas Pemerintah Pusat.

Peraturan Pemerintah No. 08 Tahun 2006 Tentang Pelaporan Keuangan dan Kinerja Instansi Pemerintah.

http://www.djpk.depkeu.go.id/attach/post-pp-no-8-tahun-2006-tetang-pelaporankeuangan-dan-kinerja-instansi-pemerintah/PP82006LAKIP.pdf di akses pada 25 Agustus 2017 ,

Peraturan Pemerintah Republik Indonesia No. 07 Tahun 1999 Tentang Pengawetan jenis Tumbuhan dan Satwa.

http://storage.jakstik.ac.id/ProdukHukum/kehutanan/PERATURAN\%20PEMERINTAH\%20REPUBLIK \%20INDONESIA\%20NOMOR\%207\%20TAHUN\%201999.pdf di akses pada 6 Oktober 2017 
Peraturan Pemerintah Republik Indonesia No. 08 Tahun 1999 Pemanfaatan Jenis Tumbuhan da Satwa Liar.

https://frankyzamzani.files.wordpress.com/2007/06/pp-no-8-th-1999-ttg-pememfaatanjenis-tumbuhan-dan-satwa-liar.pdf di akses pada 6 Oktober 2017

Wild J. J, Subramanyam K.R and Halsey R. F .2008. Financial Statement Analysis. Edisi 8 Buku 1 Mc Graw Hill. Salemba Empat, Jakarta 


\section{Appendix 1}

\section{Hasil Pengamatan Koleksi Satwa Kebun Binatang Medan}

\begin{tabular}{|c|c|c|c|c|c|}
\hline No & Nama & Kelas & Ordo & Familia & Status \\
\hline 1 & Nuri Kepala Hitam & Aves & Psittaciformes & Psittaculidae & Cites Appendix II \\
\hline 2 & Bayan (Burung) & Aves & Psittaciformes & Cacatuidae & $\begin{array}{l}\text { Dilindungi UU No. } 5 \text { th } 1990 . \\
\text { PP No } 7 \& 8 \text { th } 1999\end{array}$ \\
\hline 3 & Kakatua Maluku & Aves & Psittaciformes & Cacatuidae & Cites Appendix II \\
\hline 4 & Kakatua Raja & Aves & Psittaciformes & Cacatuidae & $\begin{array}{l}\text { Cites Appendix I Dilindungi } \\
\text { UU no } 5 \text { th } 1990 \text { PP No } 7 \& 8 \\
\text { th } 1999\end{array}$ \\
\hline 5 & $\begin{array}{l}\text { Kakatua Jambul } \\
\text { Kuning }\end{array}$ & Aves & Psittaciformes & Cacatuidae & $\begin{array}{l}\text { Cites Appendix I Dilindungi } \\
\text { PP No } 7 \text { \& } 8 \text { th } 1999\end{array}$ \\
\hline 6 & Merak Hijau & Aves & Galliformes & Phasianidae & $\begin{array}{l}\text { Cites Appendix II Dilindungi } \\
\text { PP No } 7 \& 8 \text { th } 1999\end{array}$ \\
\hline 7 & Bangau Tong Tong & Aves & Ciconiiformes & Ciconiidae & $\begin{array}{l}\text { Dilindungi PP No } 7 \& 8 \text { th } \\
1999\end{array}$ \\
\hline 8 & Kera Jepang & Mamalia & Primata & Cercopithecidae & - \\
\hline 9 & Ayam Mutiara & Aves & Galliformes & Numididae & - \\
\hline 10 & Burung Hantu & Aves & Stringiformes & Strigdae Nocturnal & Cites Appendix II \\
\hline 11 & $\begin{array}{l}\text { Kowak Malam Abu } \\
\text { Abu }\end{array}$ & Aves & Ciconiformes & Ardeidea & Tidak Dilindungi \\
\hline 12 & Bleok Sawah & Aves & Ciconiformes & Ardeidea & - \\
\hline 13 & Burung Kuntul & Aves & Ciconiformes & Ardeidea & $\begin{array}{l}\text { Cites Appendix III Dilindungi } \\
\text { PP No } 7 \& 8 \text { th } 1999\end{array}$ \\
\hline 14 & Elang Ular & Aves & Accipitriformes & Accipitridae & $\begin{array}{l}\text { Cites Appendix II Dilindungi } \\
\text { PP No } 7 \& 8 \text { th } 1999\end{array}$ \\
\hline 15 & Elang Ular Bido & Aves & Accipitriformes & Accipitridae & Cites Appendix II \\
\hline 16 & Elang Bondol & Aves & Falconiformes & Accipitridae & $\begin{array}{l}\text { Cites Appendix II Dilindungi } \\
\text { PP No } 7 \& 8 \text { th } 1999\end{array}$ \\
\hline 17 & Kura - Kura & Reptile & Testudinae & Ernydidae & - \\
\hline 18 & Kura - Kura Brazil & Reptile & Psittaciformes & Cacatuidae & $\begin{array}{l}\text { Dilindungi PP No } 7 \& 8 \text { th } \\
1999\end{array}$ \\
\hline 19 & Penyu Sisik & Reptile & Testudinata & Cheloniidae & Cites Appendix III \\
\hline 20 & Dara Mahkota & Aves & Columbiformes & Columbidae & $\begin{array}{l}\text { Cites Appendix II Dilindungi } \\
\text { PP No } 7 \& 8 \text { th } 1999\end{array}$ \\
\hline 21 & Landak & Mamalia & Rodenti & Hystricideage & Cites Appendix III \\
\hline 22 & Merpati & Aves & Columbiformes & Columbidae & Cites Appendix III \\
\hline 23 & Ayam Kalkun & Aves & Galliformes & Phasianidae & - \\
\hline 24 & $\begin{array}{l}\text { Elang Laut Perut } \\
\text { Putih }\end{array}$ & Aves & Falconiformes & Accipitridae & $\begin{array}{l}\text { Cites Appendix I PP No } 7 \& 8 \\
\text { th } 1999\end{array}$ \\
\hline 25 & Harimau Sumatera & Mamalia & Carnivora & Felidae & $\begin{array}{l}\text { Cites Appendix I Dilindungi } \\
\text { UU no } 5 \text { th } 1990 \text { PP No } 7 \& 8 \\
\text { th } 1999 \text {, Cites Appendix I }\end{array}$ \\
\hline 26 & Harimau Benggala & Mamalia & Carnivora & Felidae & - \\
\hline 27 & Beruang Madu & Mamalia & Carnivora & Ursidae & $\begin{array}{l}\text { Cites Appendix I Dilindungi } \\
\text { UU no } 5 \text { th } 1990 \text { PP No } 7 \& 8 \\
\text { th } 1999\end{array}$ \\
\hline 28 & Rusa Tutul & Mamalia & Artiodactyla & Cervidae & - \\
\hline 29 & Rusa Timor & Mamalia & Artiodactyla & Cervidae & PP No $7 \& 8$ th 1999 \\
\hline 30 & Biawak & Reptile & Squamata & Varanidae & Cites Appendix II \\
\hline 31 & Kucing Emas & Mamalia & Carnivora & Felidae & Dilindungi \\
\hline 32 & Ular Sanca Jarring & Reptile & Squamata & Phiyhonidae & Cites Appendix II \\
\hline
\end{tabular}




\begin{tabular}{|c|l|l|l|l|l|}
\hline 33 & Rusa Sambar & Mamalia & Artiodactyla & Cervidae & $\begin{array}{l}\text { Dilindungi PP No 7 \& 8 th } \\
1999\end{array}$ \\
\hline 34 & Buaya Muara & Reptile & Crocodilia & Crocodylidae & $\begin{array}{l}\text { Dilindungi PP No 7 \& 8 th } \\
\text { 1999. Cite Appendix I/II }\end{array}$ \\
\hline 35 & Buaya Senyulong & Reptile & Crocodilia & Crocodylidae & $\begin{array}{l}\text { Dilindungi PP No 7 \& 8 th } \\
\text { 1999. Cite Appendix I/II }\end{array}$ \\
\hline 36 & Kasuari & Aves & Casuariformes & Casuariidae & $\begin{array}{l}\text { Dilindungi PP No 7 \& 8 th } \\
1999 .\end{array}$ \\
\hline 37 & Kuda & Mamalia & Parissodactyla & Equidae & Tidak dilindungi \\
\hline 38 & Kelinci & Mamalia & Legomorpha & Leporidae & Tidak dilindungi \\
\hline
\end{tabular}

